\title{
Article
}

\section{The access to medicine puzzle: scaling back the negative effects of the Jordan- US Free Trade Agreement}

\author{
Barqawi, Laila
}

Available at http://clok.uclan.ac.uk/31175/

Barqawi, Laila ORCID: 0000-0003-0435-2591 (2019) The access to medicine puzzle: scaling back the negative effects of the Jordan-US Free Trade Agreement. Journal of Intellectual Property Law Practice, 14 (9). pp. 678-686. ISSN 1747-1540

It is advisable to refer to the publisher's version if you intend to cite from the work. http://dx.doi.org/10.1093/jiplp/jpz080

For more information about UCLan's research in this area go to http://www.uclan.ac.uk/researchgroups/ and search for <name of research Group>.

For information about Research generally at UCLan please go to http://www.uclan.ac.uk/research/

All outputs in CLoK are protected by Intellectual Property Rights law, including Copyright law. Copyright, IPR and Moral Rights for the works on this site are retained by the individual authors and/or other copyright owners. Terms and conditions for use of this material are defined in the policies page.

\section{CLoK}

Central Lancashire online Knowledge www.clok.uclan.ac.uk

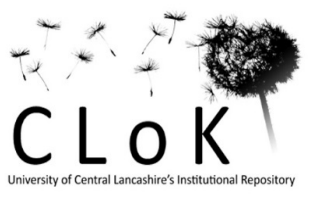


The Access to Medicine Puzzle : Scaling back the negative effects of Jordan-US FTA (JUSFTA)

Introduction

Jordan is the first Arab country which agreed to sign a Free Trade Agreement (FTA) with the US. JUSFTA contains Trade Related Aspects of Intellectual Property Rights (TRIPS) plus clauses which affect Jordan's access to medicine by raising the price of drugs, delaying generic entry of medication into the market and therefore limiting access to medicines. Concerns with FTAs have been highlighted by Abbott in that FTAs limit flexibilities such as compulsory licensing, establish strict marketing exclusivity and do not allow exceptions for fair or non-commercial use. ${ }^{1}$

The author examines recommendations by the Jordanian Food and Drug Administration (JFDA) and explains the workability of these recommendations. The author uses examples from countries which have signed FTAs with the US and have successfully curtailed the negative effects of FTAs in an attempt to assist developing countries that have been subjected to similar restrictive clauses. The author also recommends further available options which the Jordanian government can utilise to limit the negative impacts of TRIPS-plus clauses within their national laws.

The author concludes that the Jordanian government can implement national laws that do not contravene JUSFTA and TRIPS which will increase access to medicine.

\footnotetext{
${ }^{1}$ F. M. Abbott, 'The Cycle of Action and Reaction: Developments and Trends in Intellectual Property and Health', 2005. Negotiating Health: Intellectual Property And Access To Medicines, p. 31 and 32 , P. Roffe, G. Tansey and D. Vivas-Eugui, eds., Earthscan, 2005 ; FSU College of Law, Public Law Research Paper; FSU College of Law, Law, Business \& Economics Paper. Available at SSRN: http://ssrn.com/abstract=1988461
} 


\section{Jordan: Data Exclusivity and Jordan's Food and Drug Administration's (JFDA) recommendations}

Jordanian officials have started to recognise the negative impact of data exclusivity as can be seen through the JFDA's submissions to the UN High Level Panel below. The author examines these recommendations to explore their workability in an attempt to scale back the negative effects of TRIPS-plus and data exclusivity, specifically.

Data exclusivity operates as a "wholly distinct form of intellectual property rights and could not be overcome by a compulsory license.'2 Furthermore, TRIPS protects only 'undisclosed data' to prevent 'unfair commercial use'; it does not confer either exclusive rights or an automatic period of marketing monopoly. ${ }^{3}$ TRIPS does not define what constitutes 'commercial use. ${ }^{4}$ There have been arguments for data exclusivity in that it incentivises innovation of pharmaceutical drugs and assists pharmaceutical companies recoup the costs of clinical trials and clinical trial data transparency. ${ }^{5}$ These arguments have been refuted on the basis that a few years of patent protection is adequate to recover the cost of clinical trials as US companies, for example, have made an excess of USD 1 billion on 55 'blockbuster' drugs in $2013 .{ }^{6}$

As part of Jordan's WTO's accession package Jordan agreed to block registration and marketing approval of generic medicine for five years, 'even when no patents exist' ${ }^{7}$. This has been implemented through the Trade Secrets and Unfair Competition Draft Law, which had been referred

\footnotetext{
2 The Pharmaceutical Research \& Manufacturing Group of America (PhRMA), PhRMA "Special 301" Submission 185 (2005), available at members.phrma.org/international/PhRMA_2005_Special_301.pdf (arguing that CAFTA “does not permit exceptions to data exclusivity"); Letter from Martin Terberger, Head of Consumer Goods (Pharmaceuticals) Unit, European Commission on Enterprise and Industry DirectorateGeneral, to Greg Perry, European Generic Medicines Association (Feb. 20, 2006), available at www.cptech.org/ip/health/dataexcl/ec-de-tamiflu.pdf ("The European pharmaceutical legislation does not foresee any exception to the above-mentioned periods of 8 year data exclusivity and 10 years marketing protection in case of emergency situations or in case a compulsory patent licence [sic] has been granted by an EU Member State”), B. Baker ,'Ending Drug Registration Apartheid: Taming Data Exclusivity and Patent/Registration Linkage' American Journal of Law and Medicine, 2008, 34(2/3), 303-44. doi:10.1177/009885880803400209 ( Baker 2008 hereafter).

${ }^{3}$ R. Malpani, "All costs, no benefits: How TRIPS-plus intellectual property rules in the US-Jordan FTA affect access to medicines.", Oxfam briefing paper no. 102. Oxford: Oxfam International; 2007. available at https://oxfamilibrary.openrepository.com/bitstream/handle/10546/114080/bp102-all-costs-no-benefits-trips210307-en.pdf\%3Bjsessionid\%3D089750820CF675173F0C3204C369D63F\%3Fsequence\%3D1, last accessed on 12 November 2018 (hereafter Malpani 2007)

${ }^{4}$ L.Diependaele , J.Cockbain S.Sterckx , 'Raising the Barriers to Access to Medicines in the Developing World - The Relentless Push for Data Exclusivity'. Developing World Bioethics. 2017;17(1):11-21. doi:10.1111/dewb.12105. (Diependaele et al hereafter)

${ }^{5}$ Ibid

${ }^{6}$ EvaluatePharma. 2014. World Preview 2014, Outlook to 2020. Available at: http://info.evaluategroup.com/rs/evaluatepharmaltd/images/EP240614.pdf, Diependaele et al

${ }^{7}$ Ibid. See also WTO's The Working Party on the Accession to Jordan dated 3 December 1999 - WTO- 'Report of the Working Party on the accession of the Hashemite Kingdom of Jordan to the World Trade Organization' at Paragraph 215 available at file://Users/lailabarqawi/Downloads/JOR33\%20(2).pdf.
} 
to Parliament in November $1999^{8}$ and is now Article 8 of Jordan's Law No.15 of 2000 on Unfair Competition and Trade Secrets (UCTS). ${ }^{9}$ This is clearly TRIPS-plus in nature.

Moreover, restrictions by JUSFTA also require three further years for data exclusivity for new uses which clearly is an excessive form of protection for an existing TRIPS-plus condition.

The effect of this restricted use of data exclusivity is evidenced by the registered 103 medicines which were launched since 2001 that had no patent protection in Jordan; of these at least $79 \%$ had no competition from a generic equivalent as a consequence of data exclusivity. ${ }^{10}$ This-demonstrates the argument proclaiming that data exclusivity limits competition. This does not only have competition implications but financial ones as well. For example, an analysis funded by the Medicines Transparency Alliance estimated that delayed market entry of generics resulting from TRIPS-plus requirements in JUSFTA cost consumers in Jordan's retail market US\$ 18 million in $2004 .{ }^{11}$

The Jordanian government should implement the recommendations in this article with backing from the US because the US is the main financer to Jordan's economy..$^{12}$ Furthermore, defying the US means that countries such as India, which challenge the US on IP, feature regularly on the US's 'Priority Watch List' in its 301 reports. For example the USTR's 2018 Special 301 Report clearly states that India has 'Longstanding IP challenges facing US businesses in India'. ${ }^{13}$

The author examines the JFDA's recommendations below:

1. "Shortening the term of data exclusivity for new chemical entity: neither TRIPS nor JordanUS FTA request the five years." 14

\footnotetext{
${ }^{8}$ The Working Party on the Accession to Jordan dated 3 December 1999 - WTO- 'Report of the Working Party on the accession of the Hashemite Kingdom of Jordan to the World Trade Organization'.

${ }^{9}$ This states: 'Article 8 If an official party stipulated, for approving for the marketing of pharmaceuticals, or agrochemical products in which new chemical materials are used, the submission of secret formulae or any data attained through considerable efforts such party should observe the following: A. The protection of such data from the unclassified commercial use, through preventing any other person who did not obtain the applicant approval from depending thereon for marketing his pharmaceuticals and products except after 5 years as of the date of the applicant obtaining any approval for marketing his products.' Available at WIPO Lex https://wipolex.wipo.int/en/text/128322.

${ }^{10}$ Malpani 2007, See also Diependaele et al

${ }^{11}$ R.B.Abbott , R.Bader-, L. Bajjali , TA.El Samen, T.Obeidat , H.Sboul et al. The price of medicines in Jordan: the cost of trade-based intellectual property. Journal of Generic Medicines: The Business

Journal for the Generic Medicines Sector. 2012;9:75-85. (Hereafter R.B.Abbott et al)

${ }^{12}$ A. Younes, 'Jordan's economic crisis threatens political stability', 14 February 2018, Available at https://www.aljazeera.com/news/2018/02/jordan-economic-crisis-threatens-political-stability$180214112245542 . \mathrm{html}$

${ }^{13}$ USTR https://ustr.gov/sites/default/files/files/Press/Reports/2018\%20Special\%20301.pdf

${ }^{14}$ Hayel Obaidat, Wael Armouti and Wesal Haqaish ,Jordan Food Drug Administration submissions to the UN High Level Panel Report, 28 February 2016, https://highlevelpaneldevelopment.squarespace.com/inbox/2016/2/28/dr-hayel-obaidat-obaidat (Hereafter
} 
As mentioned above, Jordan has gone beyond its TRIPS obligations to provide five years of protection for data -exclusivity. ${ }^{15}$ To this effect Jordan should repeal Article 8 of Jordan's Law No.15 on Unfair Competition and Trade Secrets Law which reduces data exclusivity protection to 3 years as per JUSFTA.

Jordan should continue its efforts to re-define what constitutes a New Chemical Entity (NCE) . Jordan has succeeded in re-defining what an NCE is as per a circular dated 16 June 2009, by the JFDA's director general which states:

'A New Chemical Entity is the pharmaceutical product that contains active moiety or moieties that is responsible for physiological or pharmacological effect whereby no more than eighteen months have elapsed from the date of first registration of any of its ingredients (components) singly or collectively in any country in the world irrespective of any difference in, including but not limited to, type of salt, ester, isomer, complex or other derivative. A pharmaceutical product shall be considered to have the same chemical entity even if there is a difference in polymorph, metabolite, enantiomer, solvate, size of particles, formulation, combination, or method of use, pharmaceutical dosage form or concentration. ${ }^{16}$

Jordan has also excluded ismoers and new crystalline forms within its NCE definition. ${ }^{17}$

The author discusses how Jordan could restrict the definition of an NCE further below.

2. "Start Date of Data Exclusivity: a country can consider that the start date for granting data exclusivity is the first registration of the product worldwide." ${ }^{18}$

Jordan's start date of data exclusivity is on the date of first registration of a medicine in Jordan. This is pursuant to Article 4.22 of JUSFTA. Jordan could amend its laws to reflect the above as other

JFDA submissions to the UN), See also W. Armouti \& M. Nsour, 'Data Exclusivity for Pharmaceuticals: Was It the Best Choice for Jordan Under The US-Jordan Free Trade Agreement?', 1 August 2016, Oregon Review of International Law : Volume 17, Number 2 (2016) [4] available on https://law.uoregon.edu/images/uploads/entries/Nsour.pdf (Hereafter Armouti and Nsour 2016) ${ }^{15}$ Article 8 of Jordan's Law No. 15 of 2000 on Unfair Competition and Trade Secrets available at http://www.wipo.int/wipolex/en/text.jsp?file id=128321 provides for 5 years of data exclusivity protection \& JUSFTA at Article 4 paragraph 22 footnote 10 provides for 3 years of data exclusivity protection. 16 "Translation adopted by the JFDA. Circulation No. 2/9/1/17645, June 16, 2009" available on http://www.jfda.jo/EchoBusV3.0/SystemAssets/bd34fdc1-4ad9-48e5-b5a5-4b4250ea3d8e.tif, Armouti and Nsour 2016

${ }^{17}$ Ibid. Jordan's redefinition of an NCE was a contested issue in 2013. Merck Sharp \& Dohme (MSD) argued that Jordan's definition of an NCE violated Article 8 of the UCTS and Article 39.3 of TRIPS. The case was dismissed on grounds that the case was brought against the wrong entity without discussion of the technical issues of the NCE. Merck Sharp \& Dohme et al. v. Jordanian Food \& Drug Administration, Decision of the Jordanian High Court of Justice No. 512/2003, (Jan. 1, 2013), as cited in Armouti and Nsour 2016 ${ }^{18}$ Supra 20 
countries have done. For instance, Peru's Legislative Decree allows five-year term of data exclusivity protection 'to start concurrently from the date the product is approved in other countries with high sanitary monitoring or approval regime. ${ }^{19}$

Jordan could attempt to go farther in decreasing the existing negative effect of data exclusivity specifically as per the Chilean example by amending its national laws to limit pharmaceutical data protection availability to the year following grant of marketing approval which means that drugs' test data not marketed within the year are not protected so that the period of protection for the pharmaceutical test data starts early. ${ }^{20}$

3. "JFDA should examine the test data protection conditions before granting data exclusivity: Then, JFDA can issue a protection certificate confirming complaint of data exclusivity conditions" 21

The JFDA, in its capacity to register drugs, ${ }^{22}$ does not scrutinise test data protection and check whether it has been granted previously or not, ${ }^{23}$ and relies on the applicant's declaration. ${ }^{24}$ This recommendation requires specialised patent examiners that will be able to assess and examine test data protection conditions to grant data exclusivity.

4. "Undisclosed test data: this should be defined in the registration criteria and JFDA should examine this condition by requesting a certificate from the originator company declaring that the submitted test data have not been published by any means or in any way. If the data become non-confidential, then the JFDA has the right to end the data exclusivity period." ${ }^{25}$

The JFDA, currently, request that clinical trials ,of phase III, be published. This does not fulfil the requirement of data confidentiality at Article 39.3 of TRIPS. ${ }^{26}$ To this effect JFDA grants five years of

\footnotetext{
${ }^{19}$ Article 3 of Peru's Legislative Decree No. 1072, modified by Law No. 29316, enero 14, 2009, art. 2 (Peru), M.K.El-Said, (2016) ,TRIPS-Plus, Public Health and Performance-Based Rewards Schemes Options and Supplements for Policy Formation in Developing and Least Developed Countries, American University International Law Review: Vol. 31: Iss. 3, Article 2. Available at: http://digitalcommons.wcl.american.edu/auilr/vol31/iss3/2 (El-Said 2016 hereafter). ${ }^{20}$ Law No. 19,039 art. 90, septiembre 30, 1991, DIARIO OFICIAL [D.O.](Chile) (modified on December 1, 2005 by Law 19,996, rmias Tekeste Biadgleng \& Jean-Christophe Maur, The Influence of Preferential Trade Agreements on the Implementation of Intellectual Property Rights in Developing Countries: A First Look 1, 21 (Int'l Ctr. for Trade \& Sustainable Dev., Issue Paper No. 33, 2011); El-Said 2016.

${ }^{21}$ Supra 20

22 JFDA's website, http://www.jfda.jo/Pages/viewpage.aspx?pageID=180

${ }^{23}$ R.B. Abbott et al as quoted in Armouti and Nsour 2016

${ }^{24}$ Correa 2002, Armouti and Nsour 2016

${ }^{25}$ Supra 20

${ }^{26}$ Malpani 2007, See also Armouti and Nsour 2016.
} 
data exclusivity without checking "whether data submitted for regulatory approval has been previously disclosed." ${ }^{27}$ The JFDA, however, assesses 'the published data of Phase III.'28.

Undisclosed clinical trial data is a universal issue and various initiatives have been formed to tackle this. ${ }^{29}$ A study conducted recently has shown that only " $57 \%$ of clinical trial results for a new drug are made publicly available." 30

Jordan may implement national laws to state that if a summary of clinical studies "or of information in scientific literature" is publicly available then this is "sufficient to consider the test data as disclosed." ${ }^{\prime 31}$ For instance, in accordance with a policy applied since January 2015 by the European Medicines Agency, the information about clinical studies cannot be considered "commercial confidential information". ${ }^{32}$

While-“clinical reports may not be used to support a MAA [marketing authorisation application]/ extensions or variations to a MAA nor to make any unfair commercial use of the clinical reports" 33 the restriction does not change the nature of the information as disclosed to the extent that it is publicly available. ${ }^{34}$ In this context, Jordan could argue that such disclosures are sufficient to negate data exclusivity of a drug.

5. "Considerable efforts: this should be defined in the registration criteria and JFDA should examine this condition by requesting evidence from the originator company to show that the generation of the submitted test data involved considerable efforts by reporting the cost and the period involved in the generation of the submitted test data." ${ }^{35}$

${ }^{27}$ R. B. Abbott et al. as cited in Armouti and Nsour 2016

${ }^{28}$ Ibid

${ }^{29}$ J. Miller, 'How full disclosure of clinical trial data will benefit the pharmaceutical industry', The Pharmaceutical Journal, 15 June 2016 available at https://www.pharmaceuticaljournal.com/opinion/comment/how-full-disclosure-of-clinical-trial-data-will-benefit-the-pharmaceuticalindustry/20201274.article ( Hereafter Miller 2016), and European Medicines Agency, European Medicines Agency policy on publication of clinical data for medicinal products for human use, 2014, p. 4, available at http://www.ema.europa.eu/docs/en GB/document library/Other/2014/10/WC500174796.pdf

${ }^{30}$ Miller 2016, JE Miller, D. Korn , and JS Ross ,'Clinical trial registration, reporting, publication and FDAAA compliance: a cross-sectional analysis and ranking of new drugs approved by the FDA in 2012', BMJ Open 2015;5:e009758. doi: 10.1136/bmjopen-2015-009758

${ }^{31}$ C. M. Correa, 'Mitigating The Regulatory Constraints Imposed By Intellectual Property Rules Under Free Trade Agreements', Research Paper 47 South Centre, February 2017, available at https://www.southcentre.int/wpcontent/uploads/2017/02/RP74 Mitigating-the-Regulatory-Constraints-Imposedby-IntellectualProperty-Rules-under-Free-Trade-Agreements EN-1.pdf ( Correa 2017 hereafter)

${ }^{32}$ European Medicines Agency, European Medicines Agency policy on publication of clinical data for medicinal products for human use, 2014, p. 4, available at http://www.ema.europa.eu/docs/en GB/document library/Other/2014/10/WC500174796.pdf, Correa 2017

${ }^{33}$ Ibid

${ }^{34}$ Correa 2017

35 Supra 20 
Jordan does not examine the considerable effort element ${ }^{36}$ or have a definition ${ }^{37}$ for it despite it being a requirement of Article 39.3 of TRIPS. The JFDA should define this and require the originator company to submit a declaration or certificate stating how conditions are fulfilled. This recommendation is straightforward and is in line with other countries policies such as Peru. Peru's Legislative Decree protects cases if "generating it has involved considerable efforts" and therefore the submission of undisclosed test data is "necessary to determine the safety and efficiency of such product." 38

This has been applied by Colombia's Decree 2085 of 2002 which introduced 7 exceptions where the most relevant, to this recommendation, states that "protection does not apply to:1. Test data that are already in the public domain or have not involved considerable effort from the patent applicant to produce. ${ }^{39} "$

The benefit of fulfilling this recommendation is that Jordan will be able to "protect information against unfair commercial use' as stipulated in Article 4.22 of JUSFTA ${ }^{40}$ without having this as an ambiguous term which they are not able to utilise. Achieving this will be in line with Article 39.3 of TRIPS as well as an advantage to use Article 4.22 of JUSFTA.

6. "Data exclusivity term should not extend beyond the patent term." ${ }^{41}$

\footnotetext{
${ }^{36}$ Haqaish interview in Armouti and Nsour 2016.

${ }^{37}$ Ibid

${ }^{38}$ Article 1 of Peru's Legislative Decree No. 1072, modified by Law No. 29316, enero 14, 2009, art. 2 (Peru), El-Said 2016. Available at: h p://digitalcommons.wcl.american.edu/auilr/vol31/iss3/2

${ }^{39}$ Republica de Colombia Ministerio de Salud. Decreto Numero 2085 de 2002, as cited in Rodríguez-Garavito, C.(2014-03-13). A Golden Straitjacket?: The Struggle over Patents and Access to Medicines in Colombia. In Balancing Wealth and Health: The Battle over Intellectual Property and Access to Medicines in Latin America. : Oxford University Press. Retrieved 26 Mar. 2018, from http://www.oxfordscholarship.com/view/10.1093/acprof:oso/9780199676743.001.0001/acprof-9780199676743chapter-6. (Hereafter Rodríguez-Garavito 2014)

${ }^{40}$ Article 4.22 of JUSFTA states: ' Pursuant to Article 39.3 of TRIPS, each Party, when requiring, as a condition of approving the marketing of pharmaceutical or of agricultural chemical products that utilize new chemical entities, the submission of undisclosed test or other data, or evidence of approval in another country, the origination of which involves a considerable effort, shall protect such information against unfair commercial use. In addition, each Party shall protect such information against disclosure, except where necessary to protect the public, or unless steps are taken to ensure that the information is protected against unfair commercial use.' At footnotes 10 and 11 of Article 4.22 this states: 'It is understood that protection for "new chemical entities" shall also include protection for new uses for old chemical entities for a period of three years.' And 'It is understood that, in situations where there is reliance on evidence of approval in another country, Jordan shall at a minimum protect such information against unfair commercial use for the same period of time the other country is protecting such information against unfair commercial use'. JUSFTA

${ }^{41}$ Supra 20
} 
A study on medicine affordability in Jordan concluded that medicine prices required review to provide inexpensive medication to the poor. ${ }^{42}$ Almost $32 \%$ of the Jordanian population is not insured and will have to finance its own needs. ${ }^{43}$ A further issue that was highlighted in the said study is that 'the government is purchasing originator brands where lower-priced generics are available, which points to a lack of efficiency'. ${ }^{44}$

This clearly warrants a reviewing exercise by the JFDA to examine existing patented medication. JFDA should then produce a list of available inexpensive medication alternatives.

JFDA has been implementing a 'standing operating policy' which welcomes generic version applications from an innovator during the final year of protection which allows prompt registration of affordable generic drugs. ${ }^{45}$ This policy , if applied effectively, could also ensure that the patent term will be monitored and that data exclusivity terms will not extend beyond the patent term .

7. "Allow registration of the generic product for the purposes of export." 46

This recommendation is straightforward and is self-explanatory. Israel, for example, has removed its trade barriers and therefore allows for a generic product to be registered during the exclusivity period of the originator product for the purposes of export. ${ }^{47}$

8. "Grounds for revocation of the data exclusivity period: such as anti-competitive practices of the originator company: high prices, delay in marketing the product more than six months from approval date, stop marketing for more than six months or insufficient marketing of the product." 48

As mentioned previously JUSFTA is the only FTA which does not stipulate grounds for pre-grant or limit grounds of revocation ${ }^{49}$. This should be defined within Jordan's national legislation because the status quo means that originator companies will not be reprimanded for various acts. The author

\footnotetext{
${ }^{42}$ R. Bader et al, Medicine Prices, Availability and Affordability in Jordan, Report of a survey conducted in 2004 in Amman, Irbid, Zarqa and Karak using the WHO/HAI price measurement methodology, August 2007, available on http://apps.who.int/medicinedocs/en/d/Js17749en/ (Hereafter Bader 2007)

${ }^{43}$ Ibid

${ }^{44}$ Ibid

${ }^{45}$ JFDA submissions to the UN

${ }^{46}$ Supra 20

${ }^{47}$ A. Christie et al., 'Review of Pharmaceutical Patent Extension and Spring boarding Provisions in Various Jurisdictions', 6 November 2002, 4.6.1, available at http://achristie.com/wp-content/uploads/2011/08/IPRIAPatent-Extension-Review-2.pdf .

${ }^{48}$ Supra 20

${ }^{49}$ Krikorian and Szymkowiak 2007
} 
would add to the recommendation that grounds of revocation should include acts of inequality, misrepresentation and fraud as per the Bahrain-US FTA (BUSFTA). ${ }^{50}$

9. "Waive data exclusivity protection in cases of compulsory licensing: in case of the issuance of a compulsory license, the generic company is still required to submit clinical trials. Therefore, data exclusivity should be waived in such cases." ${ }^{51}$

Jordan's regulations could provide that "data exclusivity shall have no effects against a compulsory licensee granted for any of the grounds established under the applicable patent law, or against persons authorised to undertake a governmental non-commercial use of the patented product." ${ }^{2}$

Furthermore, Malaysia adopted similar stances to mitigate the effects of data exclusivity as per Section 5 of Malaysia's 2011 Directive of data exclusivity, entitled 'Non-Application of Data Exclusivity', which provides that:

"Nothing in the Data Exclusivity shall:

(i) apply to situations where compulsory licenses have been issued or the implementation of any other measures consistent with the need to protect public health and ensure access to medicines for all; or

(ii)prevent the Government from taking any necessary action to protect public health, national security, non-commercial public use, national emergency, public health crisis or other extremely urgent circumstances declared by the government." 53

10. "Waive data exclusivity in cases of emergency and public interest." ${ }^{54}$

Colombia succeeded in including a clause in its Decree 2085 of 2002 which states that "protection does not apply to: 4 . Information whose disclosure is necessary to protect the public interest. ${ }^{55}$ "

\footnotetext{
${ }^{50}$ BUSFTA is amongst the most restrictive FTAs, however in this instance provides clarification on revocation which is not clear in JUSFTA .BUSFTA at Article 14.8.4 limits the grounds for revoking to 'fraud, misrepresentation, or inequitable'. BUSFTA available at https://ustr.gov/trade-agreements/free-tradeagreements/bahrain-fta

51 Supra 20

${ }^{52}$ Correa 2017

${ }^{53}$ Arahan Bagi Melaksanakan Data Eksklusiviti Di Malaysia; Bilangan 2 Tahun 2011 ('Directive') http://npra.moh.gov.my/images/reg-info/DataEx/Directive on DE.pdf

${ }^{54}$ Supra 20

${ }^{55}$ Republica de Colombia Ministerio de Salud. Decreto Numero 2085 de 2002, as cited in Rodríguez-Garavito 2014 http://www.oxfordscholarship.com/view/10.1093/acprof:oso/9780199676743.001.0001/acprof9780199676743-chapter-6.
} 
This is an important waiver to include in Jordanian legislation because access to medicine is a human right, as stipulated within various international laws such as the Universal Declaration of Human Rights 1948 at Article $25^{56}$, the preamble ${ }^{57}$ and Article $1^{58}$ of 1946 Constitution of the World Health Organisation and the 1966 International Covenant on Economic, Social, and Cultural Rights. ${ }^{59}$ It is arguable that TRIPS and TRIPS-plus clauses are in conflict with human rights clauses, however this issue is beyond the scope of this article.

11. "Waive data exclusivity for products intended for the treatment of life threatening diseases." ${ }^{60}$

The above waivers in the JFDA's recommendations could be included in Jordan's national legislation laws as exceptions to limit the effects of data exclusivity. ${ }^{61}$

The above waivers are embodied within the Chilean legislation which excluded certain areas of the law from the scope of protection such as Article 91 of the Chilean law which states:

"The protection of this Paragraph shall not apply when:

(a) The owner of the test data referred to in Article 89 has engaged in forms of conduct or practices declared as contrary to free competition in direct relation to the use or exploitation of that information, according to the final decision of the free competition court.

(b) For reasons of public health, national security, non-commercial public use, national emergency or other circumstances of extreme urgency declared by the competent authority, ending the protection referred to in Article 89 shall be justified.

(c) The pharmaceutical or chemical-agricultural product is the subject of a compulsory license, according to what is established in this Law.

(d) The pharmaceutical or chemical-agricultural product has not been marketed in the national territory after 12 months from the health certificate or clearance granted in Chile.

\footnotetext{
${ }^{56}$ Article 25 of the Human Rights Declaration 1948

${ }^{57}$ This stresses on the importance of 'The extension to all peoples of the benefits of medical, psychological and related knowledge is essential to the fullest attainment of health.'

${ }^{58}$ This states: 'The objective of the World Health Organization (hereinafter called the Organization) shall be the attainment by all peoples of the highest possible level of health.'

${ }^{59}$ Health and Human Rights Resource Guide, available https://www.hhrguide.org/2017/06/09/access-tomedicines-and-human-rights/\# ftnref10

${ }^{60}$ Supra 20

${ }^{61}$ W. Armouti, and M. Nsour 'Data Exclusivity For Pharmaceuticals In Free Trade Agreements: Models In Selected United States Free Trade Agreements' , Houston Journal of International Law Vol 40:1, 9 February 2018 available at http://www.hjil.org/wp-content/uploads/Nsour-FINAL.pdf (Hereafter Armouti and Nsour 2018)
} 
(e) The pharmaceutical or chemical-agricultural product has a health certificate or clearance abroad that has been in force for over 12 months." 62

\section{Repeating Test Trials?}

Undoubtedly data exclusivity has a damaging effect on the Jordanian's public's access to affordable drugs. A solution that has been suggested by academics is that generic manufacturers could explore the option of repeating test trials to prove safety and efficacy. However, the ethics of repeating these tests is questioned ${ }^{63}$ and it is a very lengthy process that will strain time and resources that Jordanian generic manufacturers may not possess.

\section{Lenient clauses in JUSFTA? Compulsory license and Parallel Importation}

JUSFTA contains more lenient clauses when compared with other Arab-US FTAs. For example the language used in JUSFTA contains terms which are less formal than BUSFTA with phrases such as 'desiring to strengthen the bonds of friendship' ${ }^{64}$ JUSFTA's Article dealing with IP is 4 pages long whereas BUSFTA's IP Chapter is 24 pages long. ${ }^{65}$

The author refers to Article 4.20 of JUSFTA which deals with compulsory licensing and permits the usage of compulsory licensing : (1)as a remedy to an anti-competitive process, (2) 'in cases of public non-commercial use or in the case of a national emergency or other circumstances of extreme urgency', or (3) 'on the ground of failure to meet working requirements' ${ }^{66}$ This article in effect is a

\footnotetext{
${ }^{62}$ P. Roffe, Intellectual Property Provisions in Bilateral and Regional Trade Agreements: The Challenges of Implementation 15 (Oct. 6, 2006) (unpublished manuscript) (on file with the Center for International Environmental Law) (citing Decree No. 153 art. 91, Mechanisms for the Protection of Undisclosed Data, Julio 20, 2005, DIARIO OFICIAL [D.O.] (Chile)), cited in El-Said 2016

${ }^{63}$ R.G. Cartagena and A. Attaran, 2009. 'A Study Of Pharmaceutical Data Exclusivity Laws In Latin America: Is Access To Affordable Medicine Threatened?' Health Law Journal, 17, pp. 269-96.
}

${ }^{64}$ See JUSFTA's preamble in comparison with BUSFTA's preamble. USTR website, BUSFTA available at https://ustr.gov/trade-agreements/free-trade-agreements/bahrain-fta_See also_USTR, Jordan-US FTA, Side letter on marketing approval of pharmaceutical products, Available https://ustr.gov/sites/default/files/uploads/agreements/fta/jordan/asset upload file746 8466.pdf,

${ }^{65}$ Similarly see also Oman's US FTA Chapter 15 dealing with IP which is 25 pages in length available at USTR's website:

https://ustr.gov/sites/default/files/uploads/agreements/fta/oman/asset upload file715 8809.pdf and Morocco US FTA IP Chapter 15 which is 37 pages in length. Available at USTR's website:https://ustr.gov/sites/default/files/uploads/agreements/fta/morocco/asset_upload_file797_3849.pdf ${ }^{66}$ Article 4.20 of JUSFTA states: states the following:

'20. Neither Party shall permit the use of the subject matter of a patent without the authorization of the right holder except in the following circumstances:

(a) to remedy a practice determined after judicial or administrative process to be anti-competitive; 
clause for Jordan to utilise compulsory licensing and to parallel import to other countries suffering from epidemics. Compulsory licenses and parallel importation, however, have been limited by Jordan's patent laws. Article 22 of Jordan's National Law on issuing a compulsory license ${ }^{67}$ resembles the wording in Article $31(\mathrm{k})$ of TRIPS ${ }^{68}$ However Jordan's Article 22 , could be amended to allow further access to issue a compulsory license. Article 20(c) of JUSFTA states that 'failure to meet working requirements' means that a compulsory license could be issued. It is not clear what is meant by working requirements and the only 'utilization' that is stipulated is importation. ${ }^{69}$ The 'nonworking' requirement of a patent could be defined so that Jordan's national law is clear on what does not constitute 'working' or 'utilising' a patent.

Furthermore, no time limit is set to meet these 'working requirements' within JUSFTA and Jordan could repeal the requirement to exploit the patent within 3 or 4 years.

Jordan could follow the Australian example by providing separate provisions for pharmaceutical compulsory licensing to further widen the scope of compulsory licensing for patented drugs.

The above state recommendations that Jordan could implement in its own national law to restrict use of compulsory licensing. However, compulsory licensing is further diminished by data exclusivity as discussed above.

Further Recommendations to include in Jordan's National Legislation:

Policy Space

(b) in cases of public non-commercial use or in the case of a national emergency or other circumstances of extreme urgency, provided that such use is limited to use by government entities or legal entities acting under the authority of a government; or

(c) on the ground of failure to meet working requirements, provided that importation shall constitute working.

Where the law of a Party allows for such use pursuant to sub-paragraphs (a), (b) or (c), the Party shall respect the provisions of Article 31 of TRIPS and Article 5A(4) of the Paris Convention.'

${ }^{67}$ Jordan's Law No. 71 of 2001 amending the Patent Law which shall be read in conjunction with Jordan's Law No. 32 of 1999

${ }^{68}$ Article $31(\mathrm{k})$ of TRIPS states 'Members are not obliged to apply the conditions set forth in subparagraphs (b) and (f) where such use is permitted to remedy a practice determined after judicial or administrative process to be anti-competitive. The need to correct anti-competitive practices may be taken into account in determining the amount of remuneration in such cases. Competent authorities shall have the authority to refuse termination of authorization if and when the conditions which led to such authorization are likely to recur'

${ }^{69}$ Article 22.2 of Jordan's Patent Law No.71 states "For the purposes of item (1) of this paragraph, and without prejudice to the provisions of the related International Conventions, the importation of the subject goods of the patent to the kingdom shall be deemed utilization of the patent.' 
Jordan's existing policy space has been 'eroded' by signing JUSFTA ${ }^{70}$. Jordan's policy has been geared towards strengthening its patent protection ${ }^{71}$ and appeasing the US. However Jordan's remaining policy space allows Jordanian representatives to implement national laws that decrease the negative effects of JUSFTA.

Some academics argue that Jordan should consider amending its current IP laws, and suggest that Jordan consider increase spending on public health to offset the adverse impact on consumers of strengthening its IP relevant to pharmaceutical products. ${ }^{72}$ Other academics argue that the rules and provisions should be tailored to each country's national conditions ${ }^{73}$. El-Said proposes that 'current national and global models of financing and promoting medicines innovations are not working and that a new thinking should be adopted' ${ }^{74}$ The author agrees that this new thinking in terms of adapting and increasing policy space should be encouraged and built on to achieve realistic results that will not damage international relations and achieve access to health.

Jordan could allow for policy space to be interpreted within its national laws as per Peru's amended Article 4 in its Legislative Decree. ${ }^{75}$ Article 4 of Peru's Legislative Decree dictates exceptions and limitations on the right to protection of data on the grounds of protecting public health. ${ }^{76}$ Jordan could incorporate a similar article in its Patent Law No. 28 Act of 2007.

\section{Overhauling Jordan's IP system}

Overhauling Jordan's IP system means that Jordan could examine and update its laws closely to streamline its laws to achieve greater access to medicine. Australia has updated its laws and focused on six key areas which it considered essential. ${ }^{77}$ Jordan's Patent Law No.32 of 1999 has been amended twice, in 2001 and in 2007. In an effort to streamline laws it may be beneficial to have one legal document with all the amendments, to Jordan's Patent Law, rather than three separate pieces of law which repeal certain articles and add other articles into Jordan's Patent Law. Australia's Patent Act has been consolidated and a simplified outline of the laws was produced to assist Australian courts.

\footnotetext{
${ }^{70}$ Correa states that other than FTAs representing threat to policy space also WIPO's initiative to develop a Substantive Patent Law Treaty . C. Correa, Designing Patent Policies Suited to Developing Countries Needs, 10 Econômica, Rio De Janeiro 82, 87, 2008 (Hereafter Correa 2008)

${ }^{71}$ Correa 2008

72 R.B. Abbott, Access to Medicines and Intellectual Property in Jordan (July 23, 2012). Intellectual Property Watch, Forthcoming. Available at SSRN: http://ssrn.com/abstract=2116096

${ }^{73}$ K. C. Shedlen Intellectual property, trade and development: can foes be friends? Global Governance, 200713 (2). 171-177. ISSN 1075-2846

${ }^{74}$ El-Said 2016

${ }^{75}$ Article 4 of Peru's Legislative Decree No. 1072, modified by Law No. 29316, enero 14, 2009, art. 2 (Peru), El-Said 2016. Available at: http://digitalcommons.wcl.american.edu/auilr/vol31/iss3/2

${ }^{77}$ Australia's Patent Act 1990 available at: https://www.ipaustralia.gov.au/about-us/legislation/raising-bar-act
} 
Moreover, Singapore's Patent Act produced a revised edition of its patent laws which incorporates amendments. ${ }^{78}$ A consolidated streamlined approach will make it easier for the Jordanian courts to make necessary decisions especially at times of emergencies.

The author contends, however, that a more robust exercise of overhauling Jordan's IP system and updating all of Jordan's national laws, will happen as a result of a consultation with the US. The US seems to be the catalyst for Jordan's IP decisions. For example, Jordan JFDA partnership agreement with USAID, which reduces the registration time by twelve months, was forecasted to "boost pharmaceutical exports by as much as JD 17 million, yielding an additional JD21.6 million in revenue over the same period." ${ }^{\prime 79}$ The partnership also streamlined the process of drug testing and building of JFDA staff so that drugs reach the Jordanian market ${ }^{80}$. This partnership, however will ensure that the US's agenda will carry the day but nevertheless, it increases access to medicine without impairing Jordan's relationship with the US .

\section{Cap on Drug Prices}

The Jordanian government could also put a cap on drug prices. Jordan's current pricing system depends on the pricing of originator country's pricing. ${ }^{81}$ There are provisions in place to regulate drugs prices but these are not always followed. For example, a first time locally manufactured generic drug is priced at around $75-80 \%$ of the originator's company's price. ${ }^{82}$ Further drugs in the same category are priced according to the lowest price for other branded drugs. Imported generics pricing differs as the price in the drug's originator country as well as neighbouring countries are considered. Patented drugs' pricing depends on the originator country and 'several' European countries where the drug is registered along with 'the price of similar products, if any, within Jordan and the extent to which Jordanian patients can benefit from the introduction of a new drug. ${ }^{93}$ This is in comparison with other similar economies as per the Colombian example.$^{84}$ It should be noted, however, that this

\footnotetext{
${ }^{78}$ See WIPO, Singapore, Patents Act (Chapter 221) (Revised Edition 2005, as amended up to the Patents (Amendments) Act 2017), https://wipolex.wipo.int/en/legislation/details/18280

${ }^{79}$ JFDA, 'Jordan Food and Drug Administration Partners with USAID to Boost Competitiveness of Pharmaceutical Industry', 4 April 2017, available on http://www.jfda.jo/DetailsPage/Ar/NewsDetails.aspx?PID=388, last accessed on 20 August 2018

80 Jordan times, 'JFDA partners with USAID to boost pharmaceutical industry', April 2017 available at http://jordantimes.com/news/local/jfda-partners-usaid-boost-pharmaceutical-industry

${ }^{81} \mathrm{~K}$. Singh, (2012, Jun 10). Cost-based pricing to hit exports, says Indian pharmaceutical alliance pharmaceuticals]. The Economic Times Retrieved from https://search.proquest.com/docview/1019441170?accountid=17233

${ }^{82}$ Global Investment House, Jordan Pharmaceutical Sector The healing touch of Dead Sea, June 2007, available on http://www.jordanecb.org/library/6344486627045122500.pdf

${ }^{83}$ Ibid

${ }^{84}$ Rodríguez-Garavito 2014
} 
has not necessarily reaped benefits as drug prices remained high in Colombia. The stance, however, would be a shift in the right direction for Jordanians' access to medicine.

India ,for example, has managed to fix prices of 348 essential drugs and their combinations making them more affordable to patients ${ }^{85}$ The method used is a cost based price mechanism which regulates prices of drugs comprising of 74 bulk ingredients. ${ }^{86}$

\section{Recommendations on Patentability Criteria}

Jordan should consider restricting the scope of patentability in its IP law, and in particular, consider replicating India's definition of scope of patentability as mentioned previously ${ }^{87}$

Article 22 paragraph $10^{88}$ of JUSFTA protects new uses of known substances. JUSFTA includes exceptions for diagnostic, therapeutic and surgical methods and, although JUSFTA does not cite plants or animals as patentable, it does not exclude them from patentability ${ }^{89}$

The definition of an NCE in Jordan, above, does not include "products that contain salts, esters, or variants of active principles already incorporated in products ${ }^{90}$ and Jordan may amend its national regulation to "limit the protection to cases where there is a new "active moiety", as provided for under US legislation. ${ }^{91}$ This, in effect, means "protection should not be granted to test data relating to products containing chemical entities with a functional unit contained in a previously approved product, such as when marketing approval of a prodrug for an already registered drug is applied for. ${ }^{92}$

Jordan could go further in restricting the definition of an NCE as per the Peruvian government where this is defined in great detail. ${ }^{93}$ Article 2 of Peru's Amended Legislative Decree No. 1072 states:

\footnotetext{
${ }^{85}$ Supra 89

${ }^{86} \mathrm{Ibid}$

${ }^{87}$ Malpani 2007.

${ }^{88}$ G.P Krikorian, D.M and Szymkowiak, 'Intellectual Property Rights in the Making: The Evolution of Intellectual Property Provisions in US Free Trade Agreements and Access to Medicine'. The Journal of World Intellectual Property, 2007, 10: 388-418. doi: 10.1111/j.1747-1796.2007.00328.x ( Hereafter Krikorian and Szymkowiak 2007)

${ }^{89} \mathrm{Ibid}$

${ }^{90}$ Correa 2017.

${ }^{91}$ Section 505(b) of the US Federal Food, Drug, and Cosmetics Act; article 4.2(i) of the Malaysian Directive on Data Exclusivity, 2011, available at http://npra.moh.gov.my/images/reg-info/DataEx/Directive on DE.pdf, as quoted in Correa 2017.

${ }_{92}$ Correa 2017.

${ }^{93}$ Peru's Legislative Decree No. 1072, modified by Law No. 29316, enero 14, 2009, art. 2 (Peru), El-Said 2016. Available at: h p://digitalcommons.wcl.american.edu/auilr/vol31/iss3/2
} 
"A new chemical entity is understood as a biologically active fraction, responsible for the pharmacological or physiological action of an active principle, which at the moment of the Sanitary Registration request has not been included in sanitary registrations previously granted in the country.

Under no circumstance, will NCE be considered as:

1. Different therapeutic uses or indications from those authorized in other previous sanitary registrations of the same chemical entity or combinations of known chemical entities.

2. The changes in the way of administrating it, in the dosage ways, in the modifications in pharmacokinetics, in the dissolving time and in the bioavailability, authorized in other previous sanitary registrations of the same chemical entity.

3. The changes in pharmaceutical forms or in formulations of chemical entities already registered.

4. The salts (including salts with hydrogen bonds), esters, ethers, complexes, chelates, clathrates, isomers, metabolites, co-crystals, polyphorms, solvates, pure forms, particle sizes, prodrugs, or those chemical structures notwithstanding their forms, disposition or expression that are based on a previously registered chemical entity.

5. The combination of an already known chemical entity and a new one."94

Colombia has also been able to limit the effects of its Colombia-US FTA by introducing 7 exceptions in its Decree 2085 of 2002 which is similar to what has been suggested and the most relevant exceptions state that:

"Protection does not apply to:

2. Data on chemical entities that are already in the market. Thus, protection does not apply to minor changes to such data, e.g., those pertaining to new usages of a drug that has already been patented, new combinations of known chemical entities, new dosages, or different packaging. ${ }^{95}$

3. Information on a new chemical entity that is similar to another one that has been commer- cialized in Colombia and whose protection period has expired. ${ }^{96}$

${ }^{94}$ WIPO, Article 2, Legislative Decree $N^{\circ} 1072$ Protection Of Undisclosed Test Data Or Other Undisclosed Data Related To Pharmaceutical Products available at http://www.wipo.int/edocs/lexdocs/laws/en/pe/pe047en.pdf ${ }^{95}$ Supra 63

${ }^{96}$ Ibid 
5. Data on a new chemical entity that is not commercialized within a year from the expedition of the marketing authorization." ${ }^{97}$

Other terms that can also be defined in favour of widening the scope of Jordanian's access to medicine within policy are "unfair commercial use," "considerable effort," and "necessary to protect the public." 98

Jordan could go one step further and emulate the Australian example by raising the quality of granted patents by aligning patentability standards with international standards. ${ }^{99}$ Australia has been able to raise the quality of its granted patents by targeting the inventive and innovative step ${ }^{100}$, usefulness ${ }^{101}$, provisional specification ${ }^{102}$, disclosure in patent applications ${ }^{103}$, fair basis ${ }^{104}$, priority dates,${ }^{105}$

\footnotetext{
${ }^{97}$ Ibid

${ }^{98}$ Shreya Matilal, 'Do Developing Countries Need a Pharmaceutical Data-exclusivity

Regime?', 32 EUR. INTELL. PROP. REV. 268, 272-75 (2010), Armouti and Nsour 2016

99 "The IP Laws Amendment (Raising the Bar) Act 2012 is Australia's biggest intellectual property (IP) system overhaul in twenty years. The Act came into full effect on 15 April 2013.' Australia's Patent Act 1990 available at: https://www.ipaustralia.gov.au/about-us/legislation/raising-bar-act

${ }_{100}$ Australia's Patent Act 1990 subsection 7(2) and 7(4) 'removes the geographical limitation on the common general knowledge when assessing inventive step in a standard patent application and innovative step in an innovation patent. Subsection 7(3) - removes the requirement that prior art documents for inventive step be limited to only those documents that would have been 'ascertained, understood and regarded as relevant' by the skilled person.', Commonwealth of Australia 2013, Intellectual Property Reform in Australia: A summary of important legislative changes', July 2013, IP Australia, available at https://www.ipaustralia.gov.au/sites/g/files/net856/f/ip reform in australia july 2013 final.pdf

${ }^{101}$ Australia's Patent Act 1990 at Section 7A stipulates that the patent specification must include a specific, substantial and credible use for the invention.

${ }^{102}$ Australia's Patent Act 1990 at 'subsection 40(1)- raises the standard for disclosure in provisional specifications. A provisional application will only provide a valid priority date for an invention later claimed in a complete application if the provisional specification discloses the invention in a manner that is clear and complete enough for the invention to be performed by a person skilled in the relevant art. This sets a similar standard to that required for disclosure in complete application' Commonwealth of Australia 2013, Intellectual Property Reform in Australia: A summary of important legislative changes', July 2013, IP Australia, available at https://www.ipaustralia.gov.au/sites/g/files/net856/f/ip reform in australia july 2013 final.pdf
}

${ }^{103}$ Australia's Patent Act 1990 at 'Paragraph 40(2)(a) - replaces the full description requirement with the requirement that the specification discloses the invention in a manner which is clear enough and complete enough for the invention to be performed by a person skilled in the relevant art. This better aligns the Australian requirement for disclosure in a complete specification with the requirements elsewhere and ensures that the description provides sufficient information to make the invention across the full width of the claims'.

${ }^{104}$ Australia's Patent Act 1990 'Subsection 40(3) - replaces 'fair basis' with the requirement that the claims are fully supported by the description. This better aligns the Australian standards for claim scope with overseas standards.'

${ }^{105}$ Australia's Patent Act 1990 at 'Subsection 43(2) - aligns the standard for disclosure in a priority document with the standard for disclosure document discloses the invention in a manner that is clear and complete enough for the invention to be performed by a person skilled in the relevant art. This ensures that an applicant cannot secure a priority date based on a speculative or incomplete disclosure. This is the same as the disclosure standard in a provisional application and aligns Australian standards for disclosure in priority documents with most other jurisdictions.' 
preliminary search and opinion ${ }^{106}$, examination and re-examination of standard patents ${ }^{107}$, standard of proof ${ }^{108}$, non-allowable amendments ${ }^{109}$, amending definitions such as inserting "preliminary search and opinion'. ${ }^{110}$ In addition to raising examination standards and expanded examination grounds and higher standards of proof ${ }^{111}$ which has resulted in a simplified IP system that got rid of unnecessary hurdles and 'easier to use in a global setting'. ${ }^{12}$

\section{Conclusion}

There is policy space that the Jordanian government could utilise to hinder the effects of TRIPS-plus. Jordan's data exclusivity clauses are the most harmful to Jordan's access to medicine. However, this article offers practical solutions to scale back Jordan's data exclusivity restraints as implemented by other countries that have signed similar terms with the US.

This research builds on the recommendations of the JFDA by advocating further measures for the Jordanian government to increase its access to medicine. Jordan could restrict definitions such as NCE, patentability criteria and bar second use patenting, a decision that would prevent 'evergreening' of existing patents thus maintain wide access to medicines. ${ }^{113}$ Jordan's laws could also allow for policy

\footnotetext{
${ }^{106}$ Australia's Patent Act 1990 at 'Section 43 - allows the Commissioner to conduct a PSO on a standard application filed on or after 15 April 2013. An applicant will be able to request a PSO on a complete application. This will be similar to an international search and opinion and will provide applicants and the public with early information about the likely patentability of inventions where no search and examination report is likely to be made available from another office'.

${ }^{107}$ Sections 45, 98, 101G, 101M - expand the grounds considered during examination of a standard patent application, a standard patent and an innovation patent, and during opposition of an innovation patent, to include usefulness and prior use. This ensures that the Commissioner can examine on all of the substantive grounds available during opposition and court revocation proceedings.

${ }^{108}$ Commonwealth of Australia 2013, Intellectual Property Reform in Australia: A summary of important legislative changes', July 2013, IP Australia, available at https://www.ipaustralia.gov.au/sites/g/files/net856/f/ip reform in australia july 2013 final.pdf

${ }^{109}$ These are found in sections 102,114 and 114A of Australia's Patent Act 1990 see Commonwealth of Australia 2013, Intellectual Property Reform in Australia: A summary of important legislative changes', July 2013, IP Australia, available at https://www.ipaustralia.gov.au/sites/g/files/net856/f/ip reform in australia july 2013 final.pdf ${ }_{110}$ Australia Patent Act 1990 at 'Section 3 - inserts 'preliminary search and opinion' (PSO) (c), 52(2), 74(1), 74(3), 103(2), 106(1)(b), 106(4), 107(1) (b0, 107(4), 150(2), 151(2), 215(3), 223(2A)9b), 223(6A) amend existing references to the Commissioner being 'balance of probabilities'.

111 Australia Patent Act 1990 at 'Section 3 - inserts 'preliminary search and opinion' (PSO)

(c), 52(2), 74(1), 74(3), 103(2), 106(1)(b), 106(4), 107(1)

(b0, 107(4), 150(2), 151(2), 215(3), 223(2A)9b), 223(6A) amend existing references to the Commissioner being 'balance of probabilities'.

112 Australia's Patent Act 1990 available at: https://www.ipaustralia.gov.au/about-us/legislation/raising-bar-act

${ }^{113}$ Rochelle C. Dreyfuss, Creative Lawmaking: A Comment on Lionel Bently, Copyright, Translations, and Relations between Britain and India in the Nineteenth and Early Twentieth Centuries, 82 CHI.-KENT. L. REV. 1243, 1247 (2007), Beatrice Lindstrom Scaling Back TRIPS-Plus An Analysis of Intellectual Property Provisions in Trade Agreements and Implications for Asia and the Pacific https://poseidon01.ssrn.com/delivery.php?ID=70500900602102610901106906400506511003304300500005807 $\underline{002802509912500402511900908502401904903201501012605508502811900312503111005507101106505309}$
} 
space to be interpreted within its national laws as per Peru's Amended Article 4 in its Legislative Decree. ${ }^{114}$ The Jordanian government could put a cap on the drug prices in comparison with other similar economies. Consequently Jordan could attempt to overhaul its national legislation to streamline its IP. The Jordanian government should, ideally, have its decisions backed by the US to maintain its relationship with the US and not feature in the USTR's 301 Report's Watch List. 